\title{
Assessment of fructooligosaccharides production from sucrose in aqueous and aqueous-organic systems using immobilized inulinase from Kluyveromyces marxianus NRRL Y-7571
}

\author{
Avaliação da produção de fruto-oligossacarídeos a partir de sacarose em meio aquoso e orgânico usando \\ inulinase imobilizada de Kluyveromyces marxianus NRRL Y-7571
}

Fernanda Vaz Alves RISSO ${ }^{1}$, Marcio Antonio MAZUTTI ${ }^{2}$, Helen TREICHEL ${ }^{3 *}$, Fátima COSTA ${ }^{1}$, Francisco MAUGERI ${ }^{1}$, Maria Isabel RODRIGUES ${ }^{1}$

\begin{abstract}
This work investigated the fructooligosaccharides (FOS) synthesis by immobilized inulinase obtained from Kluyveromyces marxianus NRRL Y-7571 in aqueous and aqueous-organic systems using sucrose as substrate. The sequential strategy of experimental design was used to optimize the FOS conversion in both systems. For the aqueous-organic system, a $2^{6-2}$ fractional design was carried out to evaluate the effects of temperature, sucrose concentration, $\mathrm{pH}$, aqueous/organic ratio, enzyme activity, and polyethylene glycol concentration. For the aqueous system, a central composite design for the enzyme activity and the sucrose concentration was carried out. The highest fructooligosaccharides yield $\left(\mathrm{Y}_{\mathrm{FOS}}\right)$ for the aqueous-organic system was $18.2 \pm \mathrm{S} 0.9 \mathrm{wt} \%$, at $40^{\circ} \mathrm{C}, \mathrm{pH} 5.0$, sucrose concentration of $60 \%$ (w/w), enzyme activity of $4 \mathrm{U} . \mathrm{mL}^{-1}$, and aqueous/organic ratio of $25 / 75 \mathrm{wt} \%$. The highest $\mathrm{Y}_{\mathrm{FOS}}$ for the aqueous system was $14.6 \pm 0.9 \mathrm{wt} \%$ at $40{ }^{\circ} \mathrm{C}$, $\mathrm{pH} 5.0$, sucrose concentration of $60 \mathrm{wt} \%$, and enzyme activity of $4.0 \mathrm{U} \cdot \mathrm{mL}^{-1}$.
\end{abstract}

Keywords: immobilized inulinase; fructooligosaccharides synthesis; Kluyveromyces marxianus NRRL Y-7571.

\section{Resumo}

Este trabalho teve como objetivo investigar a síntese de fruto-oligossacarídeos (FOS) a partir de inulinase imobilizada de Kluyveromyces marxianus NRRL Y-7571, em meio aquoso e orgânico usando sacarose como substrato. A estratégia sequencial de planejamento experimental foi utilizada para otimizar a produção de FOS em ambos os sistemas. Para o meio orgânico, um planejamento fatorial fracionário $2^{6-2}$ foi utilizado, visando avaliar os efeitos principais da temperatura, concentração de sacarose, $\mathrm{pH}$, razão molar água/solvente orgânico, atividade da enzima e concentração de polietilenoglicol. Para o sistema aquoso, um planejamento composto central, tendo como variáveis independentes a atividade da enzima e a concentração de sacarose, foi utilizado. A maior produção de FOS foi obtida no sistema orgânico $\left(18,2 \pm 0,9 \%\right.$ (m/v), a $40{ }^{\circ} \mathrm{C}$, pH 5.0, concentração de sacarose de $60 \%(\mathrm{~m} / \mathrm{m})$, atividade enzimática de 4 U.mL $\mathrm{m}^{-1}$ e razão molar água/solvente orgânico de $25 / 75 \%$ (m/m). Em meio aquoso, a maior produção de FOS foi de $14,6 \pm 0,9 \%(\mathrm{~m} / \mathrm{m})$ a $40{ }^{\circ} \mathrm{C}, \mathrm{pH} 5,0$, concentração de sacarose de $60 \%$ (m/m) e atividade enzimática de 4,0 U.mL ${ }^{-1}$.

Palavras-chave: inulinase imobilizada; fruto-oligossacarídeos; Kluyveromyces marxianus NRRL Y-7571.

\section{Introduction}

Inulinases are enzymes (2,1- $\beta$-d-fructanohydrolase, E.C. 3.2.1.7) with an important role in the production of high fructose syrups (HFS) by the enzymatic hydrolysis of the inulin (SILVA-SANTISTEBAN; MAUGERI, 2005) and in the fructooligosaccharides (FOS) synthesis since the enzyme has significant transfructosylating activity at high sucrose concentrations (GOOSEN; VAN DER MAAREL; DIJKHUIZEN, 2008). The enzymatic production processes of FOS in aqueous systems have been extensively studied and reviewed by several authors (SANGEETHA; RAMESH; PRAPULLA, 2005; SANGEETHA; RAMESH; RAPULLA, 2004). Amongst the enzymes with high transfructosylation activity the majority are from fungi such as Aspergillus niger, Aspergillus japonicus,
Aureobasidium pullulans, and Fusarium oxysporum (SANTOS; MAUGERI, 2007). In a recent paper, Santos and Maugeri (2007) investigated the FOS synthesis in aqueous system by inulinase from sucrose using stirred and packed-bed reactors in batch and continuous process with free and immobilized enzyme from Kluyveromyces marxianus ATCC 16045. The results showed slight difference among the investigated processes.

Hydrolytic enzymes such as inulinase (E.C. 3.2.1.7) can also catalyze synthetic reactions, which are the reverse reactions of hydrolysis, in the presence of organic solvents. When the molar fraction of water in a reaction mixture is reduced by the addition of an organic solvent, it is possible to shift the equilibrium of a reversible reaction between hydrolysis and synthesis to complete

${ }^{1}$ Department of Food Engineering, Faculty of Food Engineering, State University of Campinas - UNICAMP, CP 6121, CEP 13083-862, Campinas, SP, Brazil

2 Department of Chemical Engineering, Federal University of Santa Maria - UFSM, Av. Roraima, 1000, CEP 97105-900, Santa Maria, RS, Brazil

3 College of Chemistry and Food Engineering, Federal University of Rio Grande-FURG, CP 474, CEP 96201-900, Rio Grande, RS, Brazil, e-mail: helentreichel@gmail.com

${ }^{*}$ Corresponding author 
the synthesis and achieve high yields (OGINO et al., 2007). However, most enzymes including inulinase are easy to denature and lose their catalytic activities in the presence of organic solvents. To overcome these shortcomings, it is interesting to use immobilized enzymes, which may offer advantages over free enzymes such as the possibility of reuse, continuous operations, better control of reactions, and improved stability of temperature, $\mathrm{pH}$, and organic solvents (KUMARI et al., 2008). Recent studies showed that the use of immobilized inulinase enhance temperature and $\mathrm{pH}$ stability in buffer solutions (SANTOS; OLIVEIRA; MAUGERI, 2007) and allow us to reuse the same enzyme for several cycles (SINGH; DHALIWAL; PURI , 2007).

The use of statistical tools involving Central Composite Design (CCD) and the Response Surface Methodology (RSM) has been widely used for the optimization of bioprocesses and is now a standard procedure. The CCD is an efficient strategic experimental approach to determine the optimal conditions of a multivariable system with a minimum of experiments saving time and reducing costs.

In this work, the inulinase produced by the strain Kluyveromyces marxianus NRRL Y-7571 was immobilized with sodium alginate and used for the fructooligosaccharides synthesis from sucrose in aqueous and aqueous-organic systems.

\section{Material and methods}

\subsection{Fermentation and enzyme recuperation}

Kluyveromyces marxianus NRRL Y-7571 was employed for the production of inulinase. The fermentation medium was composed of $\left(\mathrm{g} . \mathrm{L}^{-1}\right)$ : sucrose 30.0 , yeast extract 10.0 , peptone 20.0, and $\mathrm{K}_{2} \mathrm{HPO}_{4}$ 5.0. The cultures were grown at $\mathrm{pH} 3.5$. The fermentation was carried out using $10 \%$ of inoculum and incubating at $30{ }^{\circ} \mathrm{C}$ in a rotary shaker at $150 \mathrm{rpm}$ for 72 hours, according to Makino et al. (2009). The fermented medium was centrifuged at $10000 \times \mathrm{g}$ for 15 minutes, at $4{ }^{\circ} \mathrm{C}$. The precipitation of the enzyme was carried out by adding ethanol to give the supernatant a final concentration of $70 \%$. The temperature was kept as low as possible using ethanol at $-20{ }^{\circ} \mathrm{C}$ with mild agitation. After the addition of ethanol, the solution was centrifuged at $10000 \times \mathrm{g}$ for 15 minutes at $4{ }^{\circ} \mathrm{C}$. The precipitated enzyme was diluted in sodium acetate buffer $0.1 \mathrm{M} \mathrm{pH} 5.0$ and stocked at $-20^{\circ} \mathrm{C}$.

\subsection{Inulinase immobilization}

The inulinase was immobilized according to the following methodology. Initially, a gel solution containing $16.5 \mathrm{~g}$ of distilled water and $0.75 \mathrm{~g}$ of sodium alginate was prepared and maintained under brand heating. After the complete alginate dissolution, $12.5 \mathrm{~g}$ of sucrose was added. In the resulting solution, $5 \mathrm{~mL}$ of solution containing the recovered inulinase, $3.5 \mathrm{~mL}$ of glutaraldehyde, and $0.75 \mathrm{~g}$ of activated carbon were added.

For sphere formation, the gel solution was pumped into a calcium chloride $0.2 \mathrm{M}$ solution in sodium acetate buffer $0.1 \mathrm{M}$ at $\mathrm{pH} 4.8$ containing $3.5 \%$ of glutaraldehyde at $10{ }^{\circ} \mathrm{C}$ under brand agitation. The immobilized inulinase was maintained at $4{ }^{\circ} \mathrm{C}$ for 24 hours and washed with sodium acetate buffer $0.1 \mathrm{M}$ $\mathrm{pH}$ 4.8. To maintain the structure, the immobilized spheres were immersed into a calcium chloride $0.2 \mathrm{M}$ solution in the sodium acetate buffer $0.1 \mathrm{M}$ at $\mathrm{pH} 4.8$.

\subsection{Fructooligosaccharides synthesis}

The synthesis was carried out in stirred reactors $(150 \mathrm{rpm})$ with total volume of $250 \mathrm{~mL}$. The operational conditions were defined according to the experimental design planning. The reaction time for the FOS synthesis was 8 hours, and the FOSs usually produced were: GF2 (kestose), GF3 (nistose), and GF4 (fructosilnistose). In aqueous systems, the reaction medium was composed of $0.1 \mathrm{M}$ sodium acetate buffer. In the aqueousorganic system, the solvents employed were the $0.1 \mathrm{M}$ sodium acetate buffer and butyl acetate.

\subsection{Sequential strategy of experimental designs for process optimization}

The sequential strategy of experimental design was adopted to evaluate the FOS synthesis in both systems. For the aqueousorganic system, two fractional designs were carried out. Initially, the effects of temperature, $\mathrm{pH}$, sucrose concentration, enzyme activity, aqueous-organic ratio, and polyethylene concentration (PEG) were evaluated by means of a $2^{6-2}$ fractional design. Based on the results, a $2^{4-1}$ fractional design was carried out to evaluate the effects of $\mathrm{pH}$, sucrose concentration, aqueous/organic ratio, and enzyme activity. For the aqueous system, a Central Composite Rotational Design (CCRD) investigated the effect of the $\mathrm{pH}$, sucrose concentration, and enzyme activity in the FOS yield. The results were evaluated using the Statistica 7.0 software.

\subsection{Chromatographic analysis}

The samples were obtained at regular time intervals and analyzed by high-performance liquid chromatography with pulsed amperometric detection (HPLC-PAD) method to identify and quantify sugars and FOS using standard curve of kestose, nystose, and $1^{\mathrm{F}}$-fructosylnystose (Wakao Industry, Japan) and sucrose, glucose, and fructose (Merck). A Dionex DX500 system (Sunny-vale, CA, USA) ion chromatograph was utilized. This equipment consists of a GP50 gradient pump, ED40 electrochemical detector, and a CarboPac PA100 analytical anion exchange column $(250 \times 4 \mathrm{~mm})$. Gradient elution was applied using two solvents: $0.1 \mathrm{M}$ aqueous sodium hydroxide (A) and $0.1 \mathrm{M}$ aqueous sodium hydroxide containing $0.6 \mathrm{M}$ sodium acetate $(\mathrm{B})$. Both eluents were prepared with ultrapure water and degassed by nitrogen bubbling. The volume of injection was $25 \mu \mathrm{L}$. The elution began with $100 \%$ of solvent A for 10 minutes at a flow rate of $0.1 \mathrm{~mL} /$ minutes. This was followed by linear gradient from $0-90 \%$ of solvent $\mathrm{B}$ in solvent $\mathrm{A}$ for 15 minutes. Then the column was washed for 5 minutes with $100 \%$ solvent $B$. The next injection was performed after equilibrating the column with $100 \%$ solvent A for 5 minutes. 


\subsection{Inulinase assay}

The inulinase activity was measured by incubating $1.0 \mathrm{~mL}$ of immobilized spheres containing the inulinase with $9.0 \mathrm{~mL}$ of $2 \%(\mathrm{w} / \mathrm{v})$ sucrose solution at $50{ }^{\circ} \mathrm{C}$ in sodium acetate buffer (0.1 mol.L - $^{-1} \mathrm{pH} 4.8$ ) (SANTOS; MAUGERI, 2007). The reducing sugars released were measured by the 3,5-dinitrosalicylic acid method (2009) (MILLER, 1959). One unit of inulinase activity was defined as the amount of enzyme that released $1 \mu \mathrm{mol}$ of reducing sugars as glucose per minute under standard assay conditions.

\section{Results and discussion}

\subsection{Aqueous-organic system}

Table 1 presents the results obtained in the $2^{6-2}$ fractional design to evaluate the main effects of the temperature, $\mathrm{pH}$, sucrose, enzyme activity, aqueous/organic ratio, and PEG concentration on the fructooligosaccharides yield $\left(\mathrm{Y}_{\mathrm{FOS}}\right)$. A total of 19 experimental runs were carried out and a greatest variation in yield was obtained, which ranged from 0.6 to $16.0 \mathrm{wt} \%$ in the runs 9 and 14, respectively.

The results of Table 1 were employed to estimate the main effects of the independent variables, which are presented in Table 2 . The statistically significant variable $(\mathrm{p}<0.10)$ was sucrose concentration, which had a positive effect on the fructooligosaccharides yield. The effects of the other variables such as temperature, enzyme activity, aqueous/organic ratio, $\mathrm{pH}$, and $\mathrm{PEG}$ concentration were not significant in the range investigated.

With the aim of evaluating the effects of sucrose concentration on the $\mathrm{Y}_{\mathrm{FOS}}$, three additional experimental runs were carried out in triplicate at 40.0, 60.0, and $80.0 \mathrm{wt} \%$ of sucrose maintaining the temperature, $\mathrm{pH}$, aqueous/organic ratio, and enzyme activity at $40{ }^{\circ} \mathrm{C}, 5.0,75 / 25 \mathrm{wt} \%$, and $6 \mathrm{U} \cdot \mathrm{mL}^{-1}$, respectively. The PEG was not used in the reaction medium, since its effect was negative and the low level of the $2^{6-2}$ fractional design was zero. Table 3 presents the results obtained as well as the statistical analysis based on the analysis of variance (ANOVA) followed by the Tukey test $(\mathrm{p}<0.05)$. As can be seen, the highest $\mathrm{Y}_{\mathrm{FOS}}$ was obtained at $60 \mathrm{wt} \%$ of sucrose in the medium (18.2 \pm 0.9$)$, which was validated by the statistical analysis.

\subsection{Aqueous system}

Table 4 presents the results obtained in the CCRD to optimize the FOS synthesis in the aqueous system in terms of sucrose concentration and enzyme activity. A total of 11 experimental runs were carried out, and the $\mathrm{Y}_{\mathrm{FOS}}$ ranged from 5.9 to $16.5 \mathrm{wt} \%$, which were obtained at runs 8 and 5, respectively. The data presented in Table 4 were employed to build a second order model for the $\mathrm{Y}_{\mathrm{Fos}}$ as a function of the coded sucrose concentration and coded enzyme activity. The regression coefficients of the model represent the effect of the independent variables on the response.
Table 1. Matrix of the $2^{(6-2)}$ fractional design (Real and coded values) in terms of FOS yield for the aqueous-organic system.

\begin{tabular}{clllllll}
\hline Run & $\begin{array}{c}\mathrm{T} \\
\left({ }^{\circ} \mathrm{C}\right)\end{array}$ & $\mathrm{pH}$ & $\begin{array}{c}\text { Sucrose } \\
(\mathrm{wt} \%)\end{array}$ & $\begin{array}{c}\text { Enzyme } \\
\left(\mathrm{U}_{\mathrm{mL}}^{-1}\right)\end{array}$ & $\begin{array}{c}\text { Aqueous/Organic } \\
\text { Ratio (wt\%) }\end{array}$ & $\begin{array}{c}\text { PEG } \\
(\mathrm{wt} \%)\end{array}$ & $\begin{array}{c}\mathrm{Y}_{\mathrm{FOS}} \\
(\mathrm{wt} \%)\end{array}$ \\
\hline 1 & $30(-1)$ & $5(-1)$ & $50(-1)$ & $4(-1)$ & $75 / 25(-1)$ & $0(-1)$ & 8.0 \\
2 & $50(1)$ & $5(-1)$ & $50(-1)$ & $4(-1)$ & $50 / 50(1)$ & $0(-1)$ & 1.8 \\
3 & $30(-1)$ & $7(1)$ & $50(-1)$ & $4(-1)$ & $50 / 50(1)$ & $4(1)$ & 2.0 \\
4 & $50(1)$ & $7(1)$ & $50(-1)$ & $4(-1)$ & $75 / 25(-1)$ & $4(1)$ & 3.7 \\
5 & $30(-1)$ & $5(-1)$ & $70(1)$ & $4(-1)$ & $50 / 50(1)$ & $4(1)$ & 2.7 \\
6 & $50(1)$ & $5(-1)$ & $70(1)$ & $4(-1)$ & $75 / 25(-1)$ & $4(1)$ & 4.8 \\
7 & $30(-1)$ & $7(1)$ & $70(1)$ & $4(-1)$ & $75 / 25(-1)$ & $0(-1)$ & 6.3 \\
8 & $50(1)$ & $7(1)$ & $70(1)$ & $4(-1)$ & $50 / 50(1)$ & $0(-1)$ & 4.8 \\
9 & $30(-1)$ & $5(-1)$ & $50(-1)$ & $8(1)$ & $75 / 25(-1)$ & $4(1)$ & 0.6 \\
10 & $50(1)$ & $5(-1)$ & $50(-1)$ & $8(1)$ & $50: 50(1)$ & $4(1)$ & 1.7 \\
11 & $30(-1)$ & $7(1)$ & $50(-1)$ & $8(1)$ & $50 / 50(1)$ & $0(-1)$ & 1.5 \\
12 & $50(1)$ & $7(1)$ & $50(-1)$ & $8(1)$ & $75 / 25(-1)$ & $0(-1)$ & 4.3 \\
13 & $30(-1)$ & $5(-1)$ & $70(1)$ & $8(1)$ & $50 / 50(1)$ & $0(-1)$ & 7.8 \\
14 & $50(1)$ & $5(-1)$ & $70(1)$ & $8(1)$ & $75 / 25(-1)$ & $0(-1)$ & 16.0 \\
15 & $30(-1)$ & $7(1)$ & $70(1)$ & $8(1)$ & $75 / 25(-1)$ & $4(1)$ & 5.1 \\
16 & $50(1)$ & $7(1)$ & $70(1)$ & $8(1)$ & $50 / 50(1)$ & $4(1)$ & 3.1 \\
17 & $40(0)$ & $6(0)$ & $60(0)$ & $6(0)$ & $65 / 35(0)$ & $2(0)$ & 10.7 \\
18 & $40(0)$ & $6(0)$ & $60(0)$ & $6(0)$ & $65 / 35(0)$ & $2(0)$ & 10.6 \\
19 & $40(0)$ & $6(0)$ & $60(0)$ & $6(0)$ & $65 / 35(0)$ & $2(0)$ & 11.4 \\
\hline
\end{tabular}

Table 2. Estimated effects for the FOS syntheses in the aqueous-organic system obtained in the $2^{6-2}$ fractional design.

\begin{tabular}{lrcrr}
\hline & $\begin{array}{r}\text { Effects } \\
\text { Standard } \\
\text { error }\end{array}$ & $\mathrm{t}(2)$ & $\mathrm{p}$-value \\
\hline Mean & 5.62 & 0.86 & 6.51 & $<0.0001$ \\
$\mathrm{~T}\left({ }^{\circ} \mathrm{C}\right)$ & 0.78 & 1.88 & 0.41 & 0.6882 \\
$\mathrm{pH}$ & -1.58 & 1.88 & -0.84 & 0.4197 \\
Sucrose (\%) & 3.38 & 1.88 & 1.79 & 0.0986 \\
Enzyme (U.mL $\left.{ }^{-1}\right)$ & 0.75 & 1.88 & 0.40 & 0.6976 \\
Aqueous/organic ratio (\% w/w) & -2.93 & 1.88 & -1.55 & 0.1467 \\
PEG (\%) & -3.35 & 1.88 & -1.78 & 0.1009 \\
\hline
\end{tabular}

Table 3. Statistical analysis of the effect of the sucrose concentration on the $\mathrm{Y}_{\mathrm{FOS}}$ for the aqueous-organic system.

\begin{tabular}{cc}
\hline Sucrose $(\mathrm{wt} \%)$ & $\mathrm{Y}_{\text {FOS }}(\mathrm{wt} \%)$ \\
\hline 40.0 & $13.8 \pm 1.4^{\mathrm{b}}$ \\
60.0 & $18.2 \pm 0.9^{\mathrm{a}}$ \\
80.0 & $11.5 \pm 0.5^{\mathrm{b}}$ \\
\hline
\end{tabular}

${ }^{\mathrm{a}, \mathrm{b}}$ Different letters represent significant difference at $95 \%$ ( $\mathrm{p}<0.05$ - Tukey test).

Table 4. Matrix of the CCRD (Real and coded values) in terms of FOS yield for the aqueous system.

\begin{tabular}{cccc}
\hline Run & Enzyme (U.mL $\left.\mathrm{mL}^{-1}\right)$ & Sucrose $(\mathrm{wt} \%)$ & $\mathrm{Y}_{\mathrm{FOS}}(\mathrm{wt} \%)$ \\
\hline 1 & $4.4(-1)$ & $45.8(-1)$ & 9.5 \\
2 & $6.5(1)$ & $45.8(-1)$ & 10.3 \\
3 & $4.4(-1)$ & $74.1(1)$ & 11.5 \\
4 & $6.5(1)$ & $74.1(1)$ & 6.8 \\
5 & $4.0(-1.41)$ & $60.0(0)$ & 16.5 \\
6 & $7.0(1.41)$ & $60.0(0)$ & 15.4 \\
7 & $5.5(0)$ & $40.0(-1.41)$ & 8.3 \\
8 & $5.5(0)$ & $80.0(1.41)$ & 5.9 \\
9 & $5.5(0)$ & $60.0(0)$ & 8.8 \\
10 & $5.5(0)$ & $60.0(0)$ & 9.3 \\
11 & $5.5(0)$ & $60.0(0)$ & 9.7 \\
\hline
\end{tabular}


Equation 1 presents the significant terms of the model $(\mathrm{p}<0.05)$, which were validated by the analysis the variance (ANOVA). The F model value of 10.0 (2 times higher than the listed $\mathrm{F}$ values) implied that the model was significant. The model determination coefficient $\mathrm{R}^{2}(0.9091)$ suggested that the fitted model could explain $91 \%$ of the total variation.

$\mathrm{Y}_{\mathrm{FOS}}=9.27+2.85 \cdot \mathrm{E}^{2}-1.60 \cdot \mathrm{S}^{2}$

where $\mathrm{Y}_{\mathrm{FOS}}$ is the aqueous FOS yield (wt\%), $\mathrm{E}$ is de coded enzyme activity, and $S$ is the coded sucrose concentration. The significant terms in the coded model were selected based on the p-values $(\mathrm{p}<0.05)$ that serve as a tool for checking the significance of each of the coefficients. As can be seen, the significant terms in the coded model were the quadratic terms of both variables. A mathematical analysis of these coefficients indicates that there is a minimum and a maximum points in the process since the second derivatives of the $\mathrm{Y}_{\mathrm{FOS}}$ regarding the sucrose concentration and enzyme activity were negative and positive. This is a very relevant result since this kind of system is very difficult to optimize, mainly if the one-variable-at-a-time is employed because there is little information available to help overcome the difficulties imposed by the system.

The coded model was used to fit the response surface and contour plot for the FOS synthesis in aqueous system (Figure 1). One can see that the $\mathrm{Y}_{\mathrm{FOS}}$ reached an optimum value of about $16.0 \%$ for an ample range of sucrose concentration, more specifically from 55 to $75 \%$ and around 4 U.mL ${ }^{-1}$ for enzyme activity. In order to validate the model predictions, three additional runs were carried out in triplicate to evaluate the effect of sucrose concentration on the $\mathrm{Y}_{\mathrm{Fos}}$. Table 5 presents the results obtained, as well as the statistical analysis based on the ANOVA followed by the Tukey's test $(\mathrm{p}<0.05)$. As can be seen, the highest $Y_{\mathrm{FOS}}$ was obtained at $60 \mathrm{wt} \%$ of sucrose in the medium (14.6 $\pm 0.9 \mathrm{wt} \%)$, which was validated by the statistical analysis. The optimized conditions for the FOS synthesis in the aqueous system were inulinase activity $4.0 \mathrm{U} \cdot \mathrm{mL}^{-1}$, temperature $40{ }^{\circ} \mathrm{C}, \mathrm{pH} 5.0$, and sucrose concentration of $60.0 \%$.

The maximum FOS yield obtained in both aqueous and aqueous-organic systems under the optimized conditions were $14.6 \pm 0.9 \mathrm{wt} \%$ and $18.2 \pm 0.9 \mathrm{wt} \%$, respectively. A statistical analysis, based on the ANOVA followed by the Tukey's test $(\mathrm{p}<0.05)$, indicated slightly significant differences between the studied systems, in which the aqueous-organic system showed better results in terms of $\mathrm{Y}_{\mathrm{FOS}}$ using sucrose as substrate.

With regard to the aqueous system for the FOS synthesis from sucrose using inulinase as catalyst, the results obtained in this study are higher than those reported by Santos, Oliveira and Maugeri (2007), who found an $\mathrm{Y}_{\mathrm{FOS}}$ concentration of about $10 \mathrm{wt} \%$ in stirred reactor with immobilized inulinase from Kluyveromyces marxianus ATCC 16045 . When the inulin was used as substrate, the maximum inulooligosaccharide yield reported was about $72 \%(\mathrm{w} / \mathrm{w})$ with free endoinulinase from Pseudomonas sp. (YUN et al., 1997). Mutanda, Wilhelmi and Whiteley (2008) investigated the batch wise production of inulooligosaccharides from pure chicory inulin with a commercial endoinulinase preparation (Novozyme ${ }^{\bowtie} 960$ ) that was isolated from $A$. niger, and they obtained a maximum yield of $54 \%$ after 72 hours of reaction with $5 \%$ inulin at $45^{\circ} \mathrm{C}$ and $5{\mathrm{U} . g^{-1}}^{-1}$ substrate.
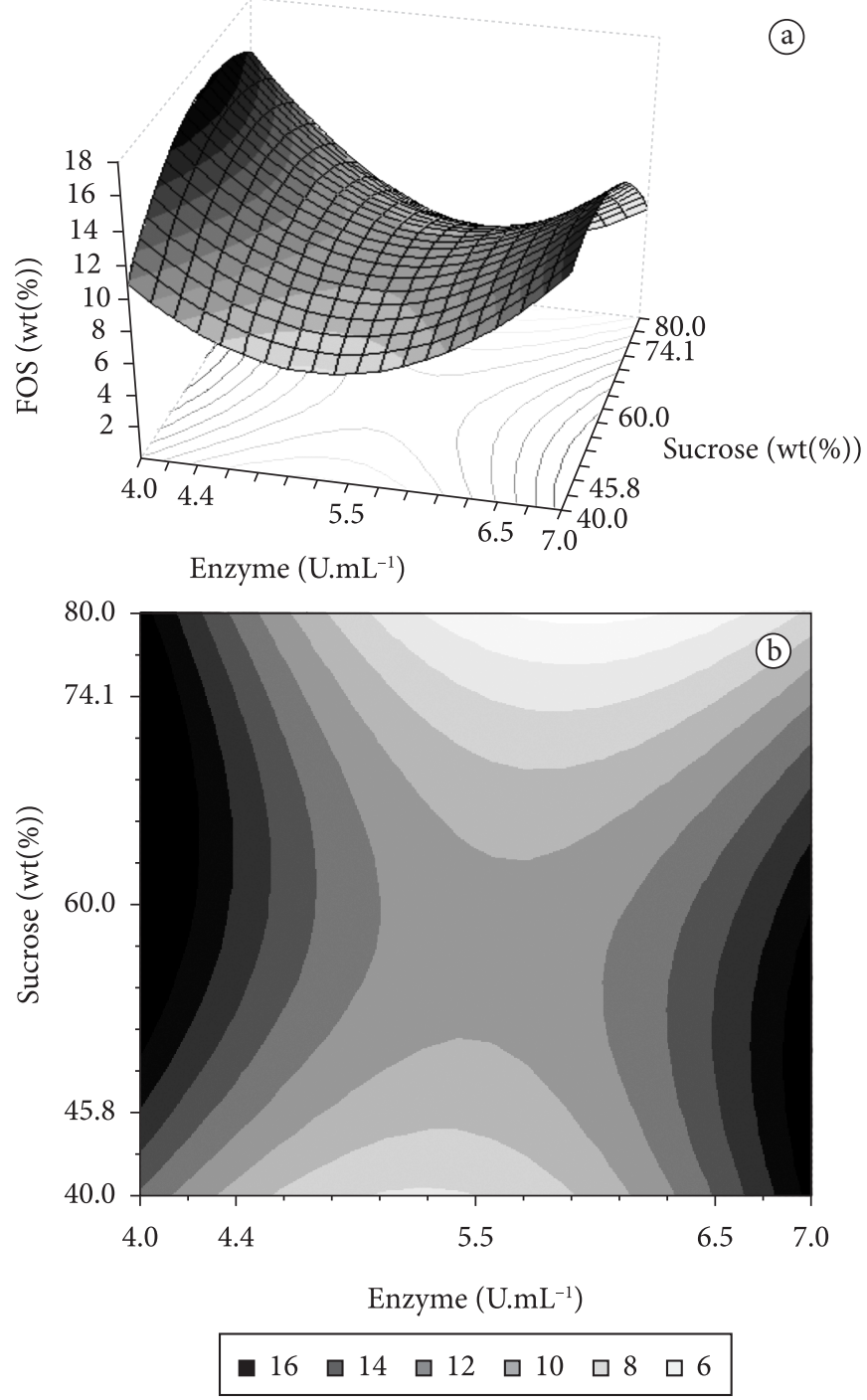

Figure 1. a) Response surface; and b) contour plot for YFOS in the aqueous system.

Table 5. Validation of model predictions for the FOS synthesis in the aqueous system and Statistical analysis of the effects of the sucrose concentration on the FOS syntheses in the aqueous system.

\begin{tabular}{cc}
\hline Sucrose $(\mathrm{wt} \%)$ & $\mathrm{Y}_{\mathrm{FOS}}(\mathrm{wt} \%)$ \\
\hline 40 & $10.6 \pm 0.8^{\mathrm{b}}$ \\
60 & $14.6 \pm 0.9^{\mathrm{a}}$ \\
80 & $6.5 \pm 0.9^{\mathrm{c}}$ \\
\hline
\end{tabular}

a,b,c.Different letters represent a significant difference at $95 \%(\mathrm{p}<0.05$ - Tukey test).

Comparing the $\mathrm{Y}_{\mathrm{FOS}}$ in the aqueous system, it can be seen that amongst the enzymes with fructosylating activities, the inulinases present the lowest values. However, this lower yield is compensated by their high productivities during fermentation and low production costs, according to the results reported by previous studies of Treichel et al. (2009) and Makino et al. (2009).

With regard to the FOS synthesis in aqueous-organic system, there are no reports in the literature, and the results 
obtained in this study are provocative since no advantageous yield was obtained comparing with the aqueous system, which is not in accordance with the technical literature. This fact can be associated with the water proportion in the aqueousorganic system that determines if the enzyme presents catalytic or hydrolytic activities. Zaks and Klibanov (1988) showed that enzymes suspended in hydrophobic solvents require substantially less water for maximal activity than those suspended in hydrophilic solvents. They stated that this phenomenon might be due to a difference in the distribution of water between the enzyme and the medium in various solvents.

\section{Conclusions}

The use of the sequential experimental design methodology proved very useful in the optimization of fructooligosaccharides by inulinase either in aqueous or aqueous-organic systems. For the aqueous-organic system, the maximum $\mathrm{Y}_{\text {Fos }}$ reached was $18.2 \pm 0.9 \mathrm{wt} \%$ under the following operational conditions: temperature of $40{ }^{\circ} \mathrm{C}$, enzyme activity of $4 \mathrm{U} \cdot \mathrm{mL}^{-1}$, aqueous/ organic ratio of $75 / 25, \mathrm{pH}$ of 5.0 , and sucrose concentration of $60 \%$. In the aqueous system, the maximum conversion obtained was $14.6 \pm 0.9 \mathrm{wt} \%$ at $40^{\circ} \mathrm{C} \mathrm{pH} 5.060 \%$ of sucrose and inulinase activity of 4 U.mL ${ }^{-1}$.

Although the yields of FOS obtained in this study for the aqueous-organic system showed better results than for those of the aqueous system, the increase in the yield is very low to justify an industrial production of FOS using organic medium since there are several drawbacks to remove this solvent from the final product before commercialization. In addition, although the yields of the FOS obtained in this study were lower than those obtained by other microorganisms, the FOS concentration in the syrup is enough for the daily recommended dietary allowance, which is about $8 \mathrm{~g}$ per adult (LOSADA; OLLEROS, 2002; YUN, 1996)

\section{Acknowledgements}

The authors acknowledge the financial support of CAPES and FAPESP.

\section{References}

GOOSEN, C.; VAN DER MAAREL, M. J. E. C.; DIJKHUIZEN, L. Exo-inulinase of Aspergillus niger N402: a hydrolytic enzyme with significant transfructosylating activity. Biocatalysis and Biotransformation, v. 26, p. 49-58, 2008. http://dx.doi. org/10.1080/10242420701806686

KUMARI, A. et al.Comparative study of thermostability and ester synthesis ability of free and immobilized lipases on cross linked silica gel. Bioprocess and Biosystems Engineering, v. 31, p. 291298, 2008. PMid:17882456. http://dx.doi.org/10.1007/s00449-0070160-X

LOSADA, M. A.; OLLEROS, T. Towards a healthier diet for the colon: the influence of fructooligosaccharides and lactobacilli on intestinal health. Nutrition Research, v. 22, n. 1, p. 71-84, 2002. http://dx.doi. org/10.1016/S0271-5317(01)00395-5
MAKINO, Y. et al. Inulinase bio-production using agroindustrial residues: screening of microorganisms and process parameters optimization. Journal of Chemical Technology and Biotechnology, v. 84, p. 1056-1062, 2009. http://dx.doi.org/10.1002/jctb.2134

MILLER, G. L. Use of dinitrosalisylic acid reagent for determination of reducing sugar. Analytical Chemistry, v. 31, p. 426-428, 1959. http://dx.doi.org/10.1021/ac60147a030

MUTANDA, T.; WILHELMI, B. S.; WHITELEY, C. G. Response surface methodology: synthesis of inulooligosaccharides with an endoinulinase from Aspergillus niger. Enzyme and Microbial Technology, 2008. http://dx.doi.org/10.1016/j. enzmictec.2008.06.005

OGINO, H. et al. Stabilities and conformational transitions of various proteases in the presence of an organic solvent. Biotechnology Progress, v. 23, p. 155-161, 2007. PMid:17269683. http://dx.doi. org/10.1021/bp060252p

SANGEETHA, P. T.; RAMESH, M. N.; PRAPULLA, S. G. Maximization of fructooligosaccharides production by two stage continuous processes and its scale up. Journal of Food Engineering, v. 68, p. 57-64, 2005. http://dx.doi.org/10.1016/j.jfoodeng.2004.05.022

SANGEETHA, P. T.; RAMESH, M. N.; RAPULLA, S. G. Production of fructo-oligosaccharides by fructosyltransferase from Aspergillus oryzea CFR 202 and Aureobasidium pullulans CFR 77. Process Biochemistry, v. 39, p. 755-760, 2004. http://dx.doi.org/10.1016/ S0032-9592(03)00186-9

SANTOS, A. M. P.; MAUGERI, F. Synthesis of fructooligosaccharides from sucrose using inulinase from Kluyveromyces marxianus. Food Technology and Biotechnology, v. 45, p. 181-186, 2007.

SANTOS, A. M. P.; OLIVEIRA, M. G.; MAUGERI, F. Modeling thermal stability and activity of free and immobilized enzymes as a novel tool for enzyme reactor design. Bioresource Technology, v. 98, p. 3142-3148, 2007. PMid:17254780. http://dx.doi.org/10.1016/j. biortech.2006.10.035

SILVA-SANTISTEBAN, B. O. Y.; MAUGERI, F. Agitation, aeration and shear stress as key factors in inulinase production by Kluyveromyces marxianus. Enzyme and Microbial Technology, v. 36, p. 717-724, 2005. http://dx.doi.org/10.1016/j.enzmictec.2004.12.008

SINGH, R. S.; DHALIWAL, R.; PURI, M. Production of high fructose syrup from Asparagus inulin using immobilized exoinulinase from Kluyveromyces marxianus YS-1. Journal of Industrial Microbiology and Biotechnology, v. 34, p. 649-655, 2007. PMid:7766065. http://dx.doi.org/10.1007/s10295-007-0237-1

TREICHEL, H. et al. Use of a sequential strategy of experimental design to optimize the inulinase production in a batch bioreactor. Journal of Industrial Microbiology and Biotechnology, v. 36, p. 895-900, 2009. PMid:7766065. http://dx.doi.org/10.1007/s10295009-0567-2

YUN, J. W. Fructooligosaccharides: occurrence, preparation and application. Enzyme and Microbial Technology, v. 19, p. 107-117, 1996. http://dx.doi.org/10.1016/0141-0229(95)00188-3

YUN, J. W. et al. Effect of inulin concentration on the production of inulooligosaccharides by soluble and immobilized endoinulinase. Journal of Fermentation and Bioengineering, v. 84, p. 365-368, 1997. http://dx.doi.org/10.1016/S0922-338X(97)89262-8

ZAKS, A.; KLIBANOV, A. M. The effect of water on enzyme action in organic media. The Journal of Biological Chemistry, v. 263, p. 8017-8021, 1988. 